\title{
Entre margens - uma leitura para o conto "A terceira margem do rio", de João Guimarães Rosa
}

\author{
Silvana@iveira'
}

\section{Introdução}

Neste artigo propomos, inicialmente, uma reflexão teórica que recupera algumas noções tradicionais sobre o discurso fantástico ${ }^{2}$ e as relaciona aos conceitos chaves de Deleuze/Guattari ${ }^{3}$, mais marcadamente, rizoma, linhas de fuga, acontecimento, agenciamento, atual e virtual, de modo a sustentar, na seqüência, uma abordagem para o conto "A terceira margem do rio", de João Guimarães Rosa, publicado pela primeira vez no livro Primeiras Estórias, em 1962.

Em Primeiras Estórias, todas as 21 narrativas, inclusive o famoso conto "A terceira margem do rio", constroem-se a partir de um motor recorrente, ou seja,: a condição comum a todas as personagens de encontrarem-se numa situação-limite provocada pela expropriação de um lugar primeiramente ocupado. Desse desterro - simbólico ou literal - resulta a consciência de não pertencer a lugar algum. $O$ indivíduo como que se ausenta para mais tarde superar a condição de expropriado propondo a inserção de um elemento novo uma linha de fuga - não prevista naquela condição inicial da personagem.

As personagens que passam pelo processo descrito acima são, no geral: crianças, que não sofreram ainda os efeitos

\footnotetext{
${ }^{1}$ Doutora em Teoria Literária pela Unicamp e professora adjunta do Departamento de Letras Vernáculas da UEPG.

${ }^{2}$ MALRIEU, Joel. Le Fantastique. Paris: Ed. Hachette, 1992.

${ }^{3}$ DELEUZE, Gilles \& Guattari, Felix. Mil Platôs - capitalismo e esquizofrenia. Vol.1. São Paulo: Editora 34, 1995. 
do tempo e do espaço sobre si ("As Margens da Alegria", "Os Cimos"); criança anormal, fora, portanto, das limitações do aqui/agora ("A menina de lá"); velhos fora do juízo, isto é, livres das convenções sofridas ao longo de suas vidas, isentos de responsabilidade devido à alienação de tempo e espaço em que se encontram ("A Terceira margem do rio"); os loucos e outros seres de exceção, vitimados pela excessiva pobreza ou sofrimento ("Sorôco, sua mãe, sua filha").

Essas personagens vivem uma situação inicial de seres extraordinários num mundo regido por regras que lhes são estranhas. Dessa estranheza resulta o conflito - primeiro estado - desencadeador da ação no conto; a solução esperada para o conflito das personagens dentro das regras do mundo em que vivem corresponderia ao segundo estado. É preciso esclarecer que o segundo estado é algo que se pode prever no desenrolar do enredo, mas que efetivamente não ocorre na narrativa, uma vez que o que vemos é algo que não se espera, ou seja, algo que não corresponde à lógica causal. $O$ que acontece e precisa ser visto é o milagre: o terceiro estado, que aparece como uma solução narrativa inesperada, na lógica da peripécia aristotélica, mas instaurando uma nova condição para as personagens inicialmente representadas em situação de alienação e expropriação.

A categoria do terceiro estado será desenvolvida neste artigo por meio da relação entre a dinâmica narrativa de João Guimarães Rosa, o pensamento de Deleuze e Guattari e a tradição do discurso fantástico.

\section{O terceiro estado como categoria teórica}

Interessa-nos, a partir daqui, a noção de acontecimento em Deleuze ${ }^{4}$, cujo sentido liga-se diretamente à idéia de encontro; se há encontro há acontecimento. Acontecimento como evento extra-corpóreo, ou seja, acontece entre os corpos. O encontro pode ser meramente extensivo, e então não haverá potência, ou intensivo, e aí há potência. É porque

${ }^{4}$ Idem, p. 14. 
tem intensidade no acontecimento que ele tem um sentido absolutamente de dificil apreensão e, portanto, distinto da significação das palavras, distinto dos conceitos e distinto do sentido lógico da proposição.

O terceiro estado pode configurar-se como uma categoria teórica que busca expressar justamente a potência do encontro que, em última instância, torna possivel aos seus elementos, de ambos os lados, o devir-outro. O encontro é o que dá ao acontecimento, seja literário ou não, o seu caráter inacabado. Está-se diante do sentido em fuga; o resultado do encontro não dimensiona o ente em nível absoluto, mas o potencializa em direções imprevisíveis; direções essas que podem determinar a reversibilidade do enredo assim como propor a abertura do desfecho.

A potência da narrativa - a instauração de uma nova picada, uma vereda inédita - pode ser dita como o terceiro estado, na medida em que caracteriza a experiência da personagem de modo a propor a descontinuidade, a multiplicidade ou, ainda, a reversibilidade do enredo.

O terceiro estado é também duração. Não é absoluto, pois ele é também um processo no qual agenciamentos infinitos se atualizam. Num esquema simplificado podemos dizer que o terceiro estado adensa e potencializa o primeiro estado (conflito) e simultaneamente o segundo (solução lógica e causal), justamente por se propor como processo e não como situação de imobilidade. Ele obedece ao seguinte esquema:

\section{Primeiro estado - Terceiro estado - Segundo estado}

Assim, é possível perceber que o terceiro estado vem antes do segundo, ou seja, ocupa o meio, e de certa forma, contém o primeiro e o segundo estados, de modo a criar um novo agenciamento entre as instâncias narrativas, que em última análise tem a ver com o tempo - justificando assim a ordenação primeiro estado, terceiro estado e segundo estado. A compreensão de que o terceiro estado não pode ser confundido com um elemento pacificador para o enredo é essencial, 
na medida em que o apresentamos como fazedor de potências, em alguns casos, diretamente opostas. O melhor seria concebê-lo como um elemento dinamizador do enredo.

O esquema proposto para o terceiro estado associa-se ainda à noção do platô rizomático de Deleuze/Guattari ${ }^{5}$. Estando o platô no meio, não tem início nem fim e age por contaminação. Os autores citados lembram Gregory Bateson, para quem a palavra platô designa algo muito especial: uma região contínua de intensidades, vibrando sobre ela mesma, e que se desenvolve evitando toda orientação sobre um ponto culminante ou em direção a uma finalidade exterior. Diríamos que um platô é como um redemoinho no meio da rua ${ }^{6}$, uma vez que produz um gira-rua, e a rua perde seu estado de suporte aquietado para tornar-se elemento dinâmico.

Ao tomar o conceito de rizoma de Deleuze como auxiliar na abordagem do fantástico, podemos considerar essa modalidade literária como uma haste imprevista na história do realismo na literatura, no sentido em que apresenta uma nova possibilidade de lidar com o real, inaugurando-o sem necessariamente prender-se ao recurso clássico da mimese.

O desenlace nas narrativas fantásticas, segundo Joel Malrieu $^{7}$, se dá no momento em que o fenômeno fantástico triunfa sobre a personagem, quando esta encontra a possibilidade de afirmar a sua identidade. No momento em que isso se torna possivel na narrativa, quase sempre a personagem já sofreu um processo de aniquilamento irreversivel, mas estará, a partir da consciência de si e pelo conhecimento do fenômeno de que é vítima, apta a enfrentar sua própria aniquilação e afirmar-se humanamente diante do inumano, ou seja, do fenômeno.

Podemos dizer, então, que o sofrimento, a dúvida, a peregrinação inconsciente, o isolamento e a solidão a que se sujeitam as personagens nas narrativas fantásticas, se configuram como estágios de um itinerário que levará, ao final, à

${ }^{5}$ DELEUZE/Guattari, 1995, p. 33.

${ }^{6}$ ROSA, João Guimarães. Grande Sertão: Veredas. 9. ed. Rio de Janeiro: José Olympio Editora, 1970.

${ }^{7}$ MALRIEU, JOEL, 1992, pp.72-73. 
construção de uma consciência capaz de abarcar a revelação de si sob a ótica de um outro mundo, não aquele proposto pelo pensamento e pela ciência autorizados do momento em que o fantástico é inaugurado, ou seja, fins do século XVIII e início do XIX, mas um mundo concebido a partir de agenciamentos infinitos.

O movimento paradoxal de aniquilamento e auto-afirmação da personagem fantástica frente ao fenômeno pode apontar uma primeira aproximação à noção de terceiro estado, ou seja, diante da morte - última e mais radical experiência de solidão - a personagem fantástica poderia sucumbir silenciosamente, mas faz da própria destruição a apoteose da consciência, apropriando-se assim do fenômeno que a vitimou.

Trata-se, portanto, de verificar o quanto o aparecimento do fantástico na literatura estabelece ou desvenda platôs na realidade pretensamente árvore/decalque, fazendo-a brotar e lançar hastes de rizoma que entrarão em conexão infinita com o fora. Assim como definem os autores já citados: "Ser rizomorfo é produzir hastes e filamentos que parecem raizes, ou, melhor ainda, que se conectam com elas penetrando no tronco, podendo fazê-las servir a novos e estranhos usos".

O fantástico faz rizoma a partir do realismo histórico herdado da tradição clássica e põe fantasmas e monstros para re-dimensionar o mundo moderno. Ao apropriar-se do fenômeno pela consciência, a personagem o transforma em algo que, mesmo significando a sua destruição material, a lança para um estado que redefine a identidade do indivíduo diferentemente do que se percebia no momento inicial da narrativa, quando não havia, ainda, a revelação de si e do mundo. Em Guimarães Rosa haverá, como veremos, o esvaziamento do lugar de contraposição ocupado pela lógica no discurso fantástico.

Covizzi ${ }^{9}$ destaca o fato de em Primeiras Estórias, de

\footnotetext{
${ }^{8}$ DELEUZE/Guattari, 1995, p. 25.

${ }^{9}$ COVIZZI, Lenira Marques. O Insólito em Guimarães Rosa e Borges. São Paulo: Ática, 1978, p. 84.
} 
João Guimarães Rosa, haver uma solução/revelação para o conflito na narrativa, solução esta nem sempre racionalmente explicável. "Tem-se a sensação de se estar sendo sempre iniciado nalgum mistério que desembocará em alguma forma de estado de graca. Nesse desvelamento gradual que na maioria das vezes não termina numa explicação lógica está a essência do insólito rosiano" (sem grifo no original).

Precisamente o estado de graça alcançado pelas personagens consiste na metamorfose daquele estado imediatamente anterior, em que o sujeito se perde de si, dos outros e das referências de tempo e espaço que o norteavam, mesmo que precariamente, num momento antes.

O terceiro estado (ou o estado de graça) no qual a personagem se verá inserida em determinado momento da narrativa corresponde, nessa perspectiva, a uma potência de virtualização do estado de coisas criado pela narrativa, potência que passa diretamente por certas operações de linguagem que levam a palavra a mágicos desdobramentos. Interessa dizer, também, que as personagens dos contos são, paradoxalmente, levadas a um para além das palavras, no universo mitopoético em que a experiência é tomada a cru, sem a mediação do discurso, num universo ficcional que propõe a volta ao paraíso da absoluta apreensão e compreensão da coisa ela mesma, na imanência anterior ao nome.

O movimento do narrador será, também, paradoxal: criará sentidos que "ainda" não se traduzem pelos significados imediatos da palavra, de modo que buscará expressar-se numa dimensão irredutivel às dimensões subjetivas, objetivas e significativas das palavras. Seria como acompanhar o movimento do rizoma crescendo em uma direção que será, ao mesmo tempo, ruptura e segmentaridade dele mesmo.

Pode-se tomar de Mil Platôs, Capitalismo e Esquizofrenia - Vol I, uma indicação metodológica útil do ponto de vista tanto do narrador quanto do leitor: "Seguir sempre o rizoma por ruptura, alongar, prolongar, revezar a linha de fuga, fazê-la variar, até produzir a linha mais abstrata e a mais tortuosa, com n dimensões, com direções rompidas" ${ }^{10}$ ).

${ }^{10}$ Ibid., p. 20. 
E mais: "Sabedoria das plantas: inclusive quando elas são de raízes, há sempre um fora onde elas fazem rizoma com algo - com o vento, com um animal, com o homem" ${ }^{11}$. O milagre, aqui, consiste em apreender o real a partir de elementos imediatamente sensiveis, sem subordinação prévia a uma organização lógica. A linguagem como emblema da imanência.

Embora na sua gênese essa modalidade literária pareça ter sofrido um aprisionamento dentro dos limites do universo romântico, a partir do início do século XX o procedimento narrativo associado ao fantástico do século XIX apresenta novas possibilidades de relação da arte literária com o real, sem os limites que o pensamento racionalista já havia estabelecido nos dois últimos séculos.

O fenômeno fantástico que se apresenta nas variadas formas fantasmagóricas e monstruosas não estaria, de alguma forma, advindo pela força de um fora? Ou seja, a personagem que se vê às voltas com o fenômeno fantástico será escolhida antes de escolher a consciência do fenômeno. Assim, o relato da experiência fantástica torna-se também o percurso de uma ascese, na qual, sob o preço da própria vida, o indivíduo poderá escolher a consciência, ou melhor, uma nova consciência de si. A personagem é, assim, atravessada pelo fenômeno fantástico.

Embora a opção, neste artigo, tenha sido utilizar a expressão discurso fantástico, por entendê-lo como um gênero criativo que se configura a partir de muitas práticas diversas e tentativas de apreensão ao longo de seu desenvolvimento, a intenção mesma deste gênero parece-nos ser a de negar, ou ainda, superar a reflexão discursiva.

Tal afirmação baseia-se na intenção, quase sempre explícita, do gênero em mostrar o elemento mágico de imediato, furtando-se ao tempo de sua racionalização. A apreensão do elemento fantástico faz-se intuitivamente, num resgate do que seria, para Cassirer, a experiência primeira com o mito e com a linguagem. Em Linguagem e Mito ${ }^{12}$, o autor pergunta

\footnotetext{
${ }^{11}$ Idem.

${ }^{12}$ CASSIRER, Ernest. Linguagem e Mito. São Paulo: Perspectiva, 1972, p. 73. 
se as relações de conteúdo - que se apresentam nas construções da linguagem e nas do mito - não se explicariam a partir da forma da construção do mito e da linguagem, ou seja, a criação imediata de uma significação (o deus momentâneo) para a sensação, emoção e/ou experiência espiritual tendo como objeto o elemento imediatamente participante desta experiência: a água, o sol, uma pedra, uma árvore, etc.

Se o engendramento da linguagem, segundo Cassirer, obedece a esse processo, é preciso observar o quanto a linguagem em terceiro estado de Guimarães Rosa foge à simples objetivação neste ou naquele ente, seja água, ar ou outro elemento, pois são os procedimentos rosianos de virtualização que vão levando águas, sóis e personagens para a estranheza de um mundo que se percebe todo misturado.

Ao potencializar a palavra no sentido de apresentar de imediato um fenômeno não racional, não estaria o fantástico buscando um modo de expressão capaz de acionar o mecanismo primeiro de apreensão do mundo e das coisas, liberando a sensibilidade para um contato outro com diferençiações virtuais de uma realidade que não se esgota em suas próprias diferenciações atuais? Desta forma, é possivel conceber as picadas abertas pelo fantástico como itinerário a ser rizomatizado pela escrita de Rosa.

Malrieu $^{13}$ reconhece no desenlace das narrativas fantásticas a revelação do mundo e da personagem de si para si. Essa revelação consistiria na compreensão pela personagem, a partir do fenômeno em ação, de que "(...) par un étrange reversement, c'est le monde dit réel qui devient illusoire, et inversement, l'apparition qui constitue la seule réalité, ou plus exactement l'élément catalyseur qui permet au personnage de se rendre compte enfin de la nature profonde de cette prétendue réalité (...)"14.

O mundo revelado não coincide com o mundo em que vivia a personagem no momento inicial da narrativa e a experiência do fenômeno fantástico assume, então, um caráter

\footnotetext{
${ }^{13}$ Ibid., p. 73.

${ }^{14}$ Idem.
} 
ambíguo, pois poderá ser terrivel sob vários aspectos, mas tornará possivel à personagem apreender a realidade de modo completo e, se muitas vezes essa realidade revela-se tão ou mais terrivel do que o próprio fenômeno e será ela também a responsável pelo aniquilamento do herói fantástico, isto se dá pela soberania da razão na ordem deste mundo.

Esta realidade, em cujo ventre se escondem elementos capazes de subjugar e roubar o sentido da existência para a personagem fantástica, sobretudo pela ação reiterada de uma lógica que fundamenta inexoravelmente o mundo da personagem fantástica, restando-lhe apenas o gozo da consciência em relação ao que a cerca, contrapõe-se, em certa medida, à realidade ficcional de Guimarães Rosa, na qual se revela um mundo móvel, sujeito à ação do amor e da arte, em que a razão não funciona como fundamento ou matriz de sentidos.O fantástico propõe uma alternativa para o desenvolvimento racional e discursivo dos eventos de uma narrativa, da mesma forma que apresenta uma personagem problemática diante de um fenômeno sem a simplificação do confronto entre o herói e o mundo passivel de domínio. A razão mesmo ganha um status de obstáculo para a compreensão de si pela personagem fantástica, mas é preciso destacar que a relação com os preceitos lógicas na abordagem do humano continuam funcionando como referência para o universo fantástico. Essa dinâmica não se observa em Guimarães Rosa, pois o primado da razão não sustenta nenhuma oposição com o mundo engendrado pelo autor, como se verá na abordagem do conto A terceira margem do rio.

O terceiro estado seria, então, o instrumento de navegação para os caminhos insinuados pela obra de Rosa, capaz de converter as alucinações potencializadas pelas narrativas em sentido de algo que, no processo de leitura, revela-se essencial. A possibilidade inventada face a um conflito que traz em si a condição extraordinária da personagem que o vive corresponde ao que chamamos, aqui, de terceiro estado. Esse estado alternativo equivale a um desafio diante do desenlace lógico; representa a transgressão, o milagre propriamente dito. 
A sua característica mais importante é alterar, no momento em que se estabelece, a condição inicial da personagem ao mesmo tempo em que expõe o campo problemático no qual se aquecem virtualizações capazes de espalhar estranhezas por fora e por dentro das personagens. O conflito vivido pela personagem, em cada um dos textos, passa a ser considerado apenas como a dimensão macroscópica desse campo problemático. Novamente, o redemoinho a desestabilizar simples oposições e estabelecer dinâmicas inéditas.

Neste vértice, as narrativas de Rosa cruzam com determinado procedimento fantástico em que os eventos extraordinários ou sobrenaturais contrariam ou subvertem a ordem causal do mundo. Tal cruzamento, no entanto, precisa ser equacionado na medida em que nos contos fantásticos tradicionais há a separação física do fenômeno em relação ao protagonista, ao passo que, em Guimarães Rosa, há um labor linguageiro explorando fulgurações intensivas que ressoam em vagos encontros das palavras e das coisas.

É possivel dizer, então, que o fantástico pode auxiliar na aplicação da noção de terceiro estado à obra de Rosa, na medida em que apresenta novas formas de perceber o mundo ao mesmo tempo em que revela um mundo desconhecido; temos o novo apreendido de uma nova forma.

No esquema estabelecido para refletir sobre o "terceiro estado", a ordenação causal só se justifica para que fique clara a ruptura desta mesma ordenação. Quando apresentamos o segundo estado como a solução que se poderia esperar no desenlace dos contos, consideramos a possibilidade da leitura causal dos eventos do conto apenas para demonstrar que esta leitura não se concretiza. O segundo estado está, portanto, ausente da narrativa, só é apresentado aqui como exercício abstrato para a compreensão disto que estou chamando de terceiro estado.

Ao lançar a solução causal e lógica (segundo estado) para fora da narrativa, o texto acena com outras possibilidades de solução para o campo problemático estabelecido pelo enredo. Voltamos à imagem obsedante do redemoinho, pois o movimento de lançar fora o segundo estado e propor o tercei- 
ro como potência de soluções virtuais é a imagem mesma de um redemoinho em ação. Essas soluções estão, como diria Deleuze, na duração infinita do caráter aberto do universo. Explicamos. Deleuze acompanha as considerações de Bergson para chegar aos conceitos relacionais de movimento e multiplicidade afirmando que

Muitos filósofos já tinham dito que o todo não era nem dado nem doável; tiravam apenas a conclusão de que o todo seria uma noção desprovida de sentido. A conclusão de Bergson é muito diferente: se o todo não é doável, é porque ele é o Aberto, e porque cabe a ele mudar sem cessar ou fazer surgir algo de novo, em resumo, durar. (...) Se fosse preciso definir o todo, seria como Relação. É que a relação não é uma propriedade dos objetos: ela é sempre exterior aos seus termos. Assim, ela é inseparável do aberto, e apresenta uma existência espiritual ou mental. As relações não pertencem aos objetos, mas ao todo, com a condição de não confundi-lo com um conjunto fechado de objetos ${ }^{15}$.

A duração é mudança, o que existe e dura, o faz através da mudança provocada pela relação entre os objetos e os seres. Nesse processo perpétuo do devir, o terceiro estado se inscreve como o caráter inédito da duração, uma vez que o todo é apresentado aberto. Há linhas de segmentaridade e há linhas de fuga a partir das quais o todo se realiza no tempo.

O pensamento de Deleuze passa a ecoar uma estranha alegria ao fazer vislumbrar um estado de fé ativa, no qual o ser tomará parte numa ordem - caótica, por certo - em que as conexões acontecerão à sua revelia, mas sem prescindir de seu estado de fé, uma vez que nesta ordem de relações caóticas, há sempre o momento - resultado da fé ativa - em que o Ser se conecta com a Atividade, de alguma forma prometida a ele.

Em Deleuze, o Uno-todo é fundado em uma lógica de relações que definem a existência. No entanto, as relações, por se localizarem entre os seres e não, necessariamente nos seres, remetem à noção de nomadismo deleuzeano, que pre-

${ }^{15}$ DELEUZE, G. Cinema 1 - A imagem-movimento. São Paulo: Brasiliense, 1985 , p. 19. 
vê a ocupação do território, não segundo a lógica da partilha, mas segundo uma distribuição delirante, cujo objetivo é ocupar e não possuir o território. E ainda: "Uma tal distribuição é demoníaca, e não divina; pois a particularidade dos demônios é operar nos intervalos entre os campos de ação dos deuses, como saltar por cima das barreiras ou dos cercados, confundindo as propriedades"16.

Assim, as relações entre os objetos e entre os seres definem o caráter perpétuo do devir em constante mudança, mas a mudança não é normativa (ou sedentária); é nômade, no sentido em que reinaugura de forma imprevisível o UnoTodo, subvertendo o Mesmo em favor do Novo.

Assim é o movimento da boiada em "O Burrinho Pedrês" ${ }^{7}$, ou mesmo a fé ativa do homem em "A hora e a vez de Augusto Matraga", primeiro e último contos do livro Sagarana. Riobaldo, ao evocar o passado, o reconstrói num movimento inaugural em que está contida a experiência vivida ao mesmo tempo em que se combina o relato questionador e de organização, em Grande Sertão: Veredas.

\section{A terceira margem do rio}

Propomos, assim, uma leitura para o conto A terceira margem do rio, do livro Primeiras Estórias, publicado em 1962, depois do conjunto de contos de Sagarana e de Corpo de Baile e também da obra máxima que é o romance Grande Sertão: Veredas.

O conto será comentado aqui de modo a explicar ou pelo menos noticiar a categoria do "terceiro estado da linguagem". Categoria esta que nos parece operacional para infinitos passeios pela obra de Rosa.

Sendo o conto A terceiro margem do rio um ponto intensivo na produção de Guimarães Rosa e tantas vezes tendo sido tomado como referência para a leitura de sua metodologia de linguagem e figuração do mundo, será tomado aqui

\footnotetext{
${ }^{16}$ DELEUZE, G. Diferença e Repetição. Rio de Janeiro: Graal, 1988, p. 54.

${ }^{17}$ ROSA, João Guimarães. Sagarana.
} 
como referência para a discussão do terceiro estado da linguagem, discutido na seção anterior deste artigo.

Retomamos uma passagem de Mil Platôs - Capitalismo e Esquizofrenia, em que Gilles Deleuze e Feliz Guattari, em parceria, dizem o seguinte:

Para onde vai você? De onde você vem? Aonde quer chegar? São questões inúteis. Fazer tábula rasa, partir ou repartir de zero, buscar um começo, ou um fundamento, implicam uma falsa concepção da viagem e do movimento (metódico, pedagógico, iniciático, simbólico...). Kleist, Lenz ou Büchner têm outra maneira de viajar e também de se mover, partir do meio, pelo meio, entrar e sair, não começar nem terminar. (...) É que o meio não é uma média; ao contrário, é o lugar onde as coisas adquirem velocidade ${ }^{18}$.

É possivel apontar uma ressonância entre esse mecanismo e o conto em questão. No conto $A$ terceira margem do rio temos a narrativa em primeira pessoa de um Filho testemunha do ato surpreendente do Pai, que, já em idade adulta e lúcida, manda fazer para si uma canoa e, contrariando as expectativas, põe-se a meio de um rio que corre próximo, sem seguir viagem e sem desembarcar. O estranhamento dessa ação estarrece a todos, Filho, Mãe, irmãos e conhecidos. Quando o pai "ordeiro" e "cumpridor" manda fazer a canoa, a indignação da mãe aponta para a intenção do pai em escolher outro modo de viver - desordeiramente - em pescarias e caçadas. No entanto, há um elemento desconsiderado pela mãe, mas intuído pelo filho narrador: o pai responde a uma força de fora, à atividade do mundo, na qual atua algo que, ao mesmo tempo transcende a existência do pai e também nele se manifesta. A essa estranha força Deleuze e Guattari chamam o Todo Uno. O pai, nos diz o filho, não atende a um chamado de Deus, em figuração religiosa, ou a qualquer força mística, mas ao elemento externo do qual ele - o pai, também o filho e tudo o que está além do "eu" - é parte. O pai é escolhido antes de escolher. O homem quieto entre as margens do rio vive a potência corrediça do meio:

${ }^{18}$ DELEUZE \& Guattari, 1995, p. 37 
De dia e de noite, com sol ou aguaceiros, calor, sereno, e nas friagens terriveis de meio-do-ano, sem arrumo, só com o chapéu velho na cabeça, por todas as semanas, e meses, e os anos - sem fazer conta do se-ir do viver. Não pojava em nenhuma das duas beiras, nem nas ilhas e croas do rio, não pisou mais em terra nem capim ${ }^{19}$.

A concepção maquínica que Deleuze tem do desejo contraria a idéia de que o indivíduo é soberano sobre a terra, dono de uma autonomia anarquizante. A noção da vontade como máquina, como engrenagem e conexão, precisa ser dita em relação ao fora do indivíduo, assim o ente não é a fonte exclusiva do que pensa ou faz. "Tudo vem sempre de mais longe, e até: tudo está sempre já-ali, no recurso infinito e inumano do Uno"2o.

Para melhor compreensão do desejo/vontade como máquina articulada e articulável com o fora é necessário que sejam levadas em conta as determinações existenciais, ou ainda, o modo de existência daquele que escolhe. Desta forma, Deleuze estabelece que a verdadeira escolha é o resultado de ter sido "escolhido". O indivíduo é, nessa perspectiva, atravessado pela potência da vida inorgânica, numa constante atualização do Uno-todo. Há uma noção de automatismo na escolha, segundo Deleuze e Guattari, uma vez que a verdadeira escolha parte do fora e esvazia a subjetividade da ação, lançando o indivíduo para um estado de purificação e conexão com o que lhe é alheio.

Assim é que essa vereda nos torna para trás, para outro momento da produção de Rosa. O que é o Sete-de-Ouros, o Burrinho Pedrês de Sagarana, que sabe, desde sempre, o momento de deixar-se levar pela correnteza, confiado?

Em A terceira margem do rio, o pai escolhe escolher porque é, antes, escolhido. A ascese presente na caracterização de homem ordeiro, quieto e cumpridor, estabelece o modo de

${ }^{19}$ ROSA, João Guimarães. Primeiras Estórias. Rio de Janeiro: Nova Fronteira, 1988, p. 34.

${ }^{20}$ BADIOU, Alain. Deleuze, o Clamor do Ser. Trad. Lucy Magalhães. Rio de Janeiro: Jorge Zahar Ed., 1997, p. 19. 
existência do indivíduo que se deixa atravessar pela potência de vida externa a ele. Sua escolha tem algo de automático e despojado de vontade individual. Ainda mais, é possivel pensar no pai como o "corpo sem órgãos", conceito explorado por Deleuze ao lado daquele da "máquina desejante"21.

O "corpo sem órgãos" é o autômato purificado, a verdadeira manifestação da unicidade do Ser. O desejo deixa de ter caráter subjetivo para compor o jogo do mundo, o indivíduo vê sua atualidade (a vida em família, a casa, o trabalho, a ordem e a obrigação) deslocar-se e imobilizar-se para desfazer-se na virtualidade infinita que se torna seu estar no rio, permanentemente. Aí está o terceiro estado, um devir potencializado ao máximo, cuja força efetiva nasce da capacidade de deslocar, mobilizar e reverter/subverter o estado atual das coisas.

O terceiro estado não é o agora absoluto em sua atualidade, mas o agora infinitamente potencializado pelo devir, pela invenção suprema do futuro, pela lógica da diferença que o tempo ensina e impõe. O encontro do filho com o pai no meio movediço do rio se dá como intensidade. Há o encontro com a disparidade, com a diferença, com o incompreendido, e a narrativa do filho é a expressão do "fazer pensar" como exercício transcendente:

O encontro com a disparidade já é encontro fundamental, expressivo do campo problemático povoado de signos intensivos. Nesse encontro, a intensidade, primeiramente, faz com que a própria "sensibilidade" vá além do exercício empírico dos sentidos. Esse ir além de percepções empíricas significa que a sensibilidade é forçada ao encontro de sua potência virtual, vale dizer, que ela é elevada "ao seu exercício transcendente". Esse exercício é marcado, justamente, pela sua intensificação junto ao seu "sentiendum", diz Deleuze. Que é isso? É o nome do intensivo na ordem da sensibilidade, o nome do díspar que a desloca do seu empírico e costumeiro reconhecimento das coisas. Não é, portanto, o que se me apresenta recoberto por qualidades no exercício empírico das

${ }^{21}$ DELEUZE, Gilles \& Guattari, Felix. O anti-Édipo. Rio de Janeiro: Imago, 1976. 
minhas percepções ordinárias. É, isto sim, o próprio "ser do sensivel", é o que "só pode ser sentido" no exercício transcendente da sensibilidade, quando esta viaja num nomadismo intensivo ${ }^{22}$.

Deixar-se escolher, como faz o pai, e cumprir a escolha sem nenhuma restrição exige a conquista contra si mesmo; impossivel para a mãe e empreendida pelo filho ao longo da narrativa. O percurso do pai é anterior à narrativa e só o temos no ponto crucial em que a personagem se vê atravessada por uma determinação dentro e fora. O relato do filho, de outro modo, acompanha o processo de despojamento de si, numa viagem à margem do rio.

O núcleo familiar que compõe o conto distribui-se entre as três margens possiveis da narrativa rosiana: mãe, irmã e irmãos do lado de lá do rio, longes; o filho (personagemnarrador), do lado de cá e o pai, no meio, rio adentro, na terceira margem. Temos, portanto, Lá (onde estão os que negam a escolha do pai), Cá (o narrador, conosco, os leitores, buscando o sentido da atualidade do pai no rio) e o meio, onde permanece o pai.

Quando entra no rio, o pai divorcia-se da família, apenas o filho-narrador quer segui-lo, corajoso na totalidade da infância: "Pai, o senhor me leva junto, nessa sua canoa?"23. O pai nega a companhia do filho, mas aceita a proximidade e a colaboração.

À margem escolhida pelo pai corresponde um silêncio de isolamento profundo, na manifestação plena do Uno. Aos que, mais tarde, se deslocam, indo embora, corresponde o uso intenso da palavra, as vozes de apelo, a palavra dos parentes, vizinhos, conhecidos. Ao filho corresponde o estado intermediário; sem aderir totalmente ao silêncio do pai, o filho-narrador entrega-se à especulação angustiada do sentido da palavra, a que se diz e a que se cala. A narrativa é ela mesma uma busca de exorcismo: "Do que era que eu tinha

\footnotetext{
${ }^{22}$ DELEUZE E GUATTARI, 1995, p. 14.

${ }^{23}$ ROSA, 1988, p. 33.
} 
tanta, tanta culpa?"24.

Colocando-se no espaço intermediário entre discurso e silêncio, o narrador também ocupa a sua terceira margem. Gritos e sussurros na linguagem, como efeito de frestas, a linguagem intuitiva-especulativa do filho impõe fendas no discurso de ordem e lógica das duas beiras do rio. O relato do filho constrói para ele um corpo sem órgãos, que só então poderá ser lançado no rio, o rio adentro. O Filho precisa despreender-se de seu organismo social, civil e acionar para si, a força do fora.

Preso nas malhas da ação do pai, o filho navega num rio de palavras caladas e busca a sua ascese para encontrar, no final da narrativa, a escolha. O pensamento e a reflexão convertem-se em poder ascético que tornarão possivel ao filho deixar-se escolher: "Mas, então, ao menos, que, no artigo da morte, peguem em mim, e me depositem também numa canoinha de nada, nessa água, que não pára, de longas beiras: $e$, eu, rio abaixo, rio a fora, rio a dentro - o rio" ${ }^{25}()$.

Deixar-se escolher assume, no pensamento de Deleuze e Guattari, o sentido de destino, mas não, obviamente, o de destino grego, e sim uma perspectiva de purificação capaz de levar o ente até onde exige a força do Fora. Assim o pensamento funciona como fratura da atualidade, explosão dos limites, cavalo visionário que guiará o indivíduo até a virtualidade máxima da sua existência. Em A terceira margem do rio, o filho cavalga a palavra e irá romper sua atualidade, tal qual o pai havia feito ao transpor as margens do rio, deixando-se atravessar por uma escolha.

Em Deleuze e Guattari há ainda a noção de que a atualidade e os limites do indivíduo, tanto quanto a força de fora que o convoca a romper esses limites são feitos da mesma matéria, compõem igualmente a univocidade do Ser. Nessa perspectiva pai e filho fazem parte do Uno, apenas se deixam atravessar pela potencialidade virtual de diferentes modos. Enquanto o pai é atravessado pelo rio, o filho se deixa trans-

\footnotetext{
${ }^{24}$ Ibid., p. 36.

${ }^{25}$ Ibid., p. 39. 
passar pela narrativa, num ferimento que lhe decreta seu sentido de comunhão com o Uno.

Essa tensão se expressa no processo narrativo, que representa ainda a atualização do virtual, sendo o virtual, na concepção de Deleuze e Guattari um modo complexo de abordar o devir e suas potências. Para chegar a uma compreensão mais precisa da relação entre o virtual e o terceiro estado, retomamos o alerta repetido várias vezes pelo filósofo de que o perigo em operar com o conceito de virtual é confundi-lo com o possivel ${ }^{26}$.

A categoria do possivel diferenciar-se-á do virtual na medida em que uma coisa poderá ser dita como possível a partir da análise das características da coisa mesma; a possibilidade é pensada pelo conceito e assim se diz que a coisa é possivel, apenas não tem existência. $\mathrm{O}$ vir a ser existente ou a existência é pensada como salto, surgimento bruto, ou ainda, ato puro. Deleuze repudia essa noção de existência, uma vez que ela separa o ser real do ser possivel. O virtual é compreendido, portanto, como simultâneo ao real, ele está ali-agora; apenas vem à superficie da existência num processo - não num salto. O virtual é o processo de vir a ser.

A imagem do "salto-mortale", presente no conto "O Espelho" "27, também em Primeiras Estórias, e associada ao terceiro estado nesta apresentação, assim como em Deleuze, não nos remete à instalação abrupta de uma realidade imediatamente inaugurada. O salto mortale rosiano é suave, ato de malabarismo, fruto de um processo preparatório que resulta na atualização de uma potencialidade virtual que sempre esteve ali. É o que vemos ainda em outro conto de Primeiras Estórias, "Pirlimpsiquice" ${ }^{28}$, em que a estória oficial, a estória inventada para disfarçar os curiosos e a estória que será encenada de fato pelos alunos do Professor Perdigão existem simultaneamente, como correlatos reais de uma potência criativa que se manifesta no grupo de atores-mirins.

${ }^{26}$ DELEUZE/Guattari, 1976, pp. 113-119.

${ }^{27}$ ROSA, 1988, pp. 65-72.

${ }^{28}$ Ibid., pp. 38-46. 
Assim é a narrativa do filho em "A terceira margem...", pois já apresenta o rio-relato em que se dá a escolha capaz de igualar os dois protagonistas - pai e filho - nas suas diferenças.

Deleuze não opõe o virtual ao real, e exatamente nesse sentido podemos evocar seu pensamento para intensificar o terceiro estado.

O virtual possui uma plena realidade, enquanto virtual. Do virtual, deve-se dizer o que Proust dizia dos estados de ressonância: 'Reais sem ser atuais, ideais sem ser abstratos'; e simbólicos sem ser fictícios. O virtual deve até ser definido como uma estrita parte do objeto real - como se o objeto tivesse uma das suas partes no virtual, e nele mergulhasse como em uma dimensão objetiva ${ }^{29}$.

Assim, retomando a dinâmica proposta para a instalação do terceiro estado, como categoria analítica do discurso em Guimarães Rosa, destacamos o seguinte esquema: rativa);

primeiro estado (conflito inicial que origina a nar-

terceiro estado (potência de sentido que contraria a relação de causa e efeito no encaminhamento do enredo); do).

segundo estado (solução lógica/linear para o enre-

Esse estado de potência narrativa e de linguagem antecipa uma solução futura para o enredo de forma a propor uma atualização que se torna possivel por conter também a solução lógica/linear (segundo estado). Desta forma, o terceiro estado apresenta-se como processo dentro do real, assim como o virtual. O nomadismo de Deleuze aplica-se muito bem a essa noção de movimento perene em que o virtual é constantemente atualizado.

Acreditamos que a abertura narrativa proposta no desenlace do conto "A terceira margem do rio" pode ser tomada como uma metáfora precisa do sentido movente do virtual/

${ }^{29}$ DELEUZE, 1988, p. 269.

100 Revista de História Regional 14(2): 82-103, Inverno, 2009 
terceiro estado. O filho abandonou a margem do rio por não poder ocupar o lugar do pai na canoa, o filho não morre neste momento, tem consciência de uma falha, seu estado atual é de falência, solidão e dor, pois ele não pôde, por medo, ocupar o lugar do pai quando foi chamado. Mas o conto não termina aí, ou melhor, o conto não termina. Há algo mais para que se compreenda o desenlace: o rio.

Imagem movente, metáfora perfeita do devir permanente, o rio atualiza seu virtual incessantemente - como o pai já percebera no momento em que permanece nos meios, entre margens. E houve a narrativa, como processo de atualização do virtual paterno no filho.

A imagem do pai, buscada pelo filho, nega-se como modelo, porém, ao mesmo tempo em que prende o narrador às margens, também o liberta para a experiência da atualização de uma virtualidade própria, existência única. Pai e filho são a mesma coisa, um só na dimensão deleuzeana do Ser, mas só poderão sê-lo cada um como referência de multiplicidade original. Cada um é a parte de um Todo a exigir consciência.

\section{Considerações finais}

A abordagem ensaiada neste artigo nasceu e se realizou a partir da associação de elementos da criação rosiana a conceitos içados da obra de Deleuze e de Deleuze/Guattari, assim como da relação com a tradição do discurso fantástico. Assim, "dizer" a obra de Guimarães Rosa tornou-se, antes de tudo, um movimento progressivo da intuição, no sentido de entrosar a criação do autor com o pensamento dos dois filósofos. O discurso fantástico, visto sob a ótica de Deleuze, poderia ser pensado como um recurso narrativo-literário em que se tomam dados até então inconciliáveis - como a realidade tangivel e fenômenos sobrenaturais - como elementos da mesma unidade, não como partes componentes, mas como "um só", num princípio de unidade absolutamente radical, em que nem mesmo a concepção dialética encontra respaldo. 
O método de Deleuze apresenta-se como uma antidialética, no sentido em que recusa o recurso às mediações. A mediação dialética aparece como um limite, pois funciona como pacificadora das explosivas diferenciações que ocorrem no meio rizomático. Esse meio não é mediador entre opostos a serem superados; é onde podem ocorrer opostos molares, como proletários e burgueses no meio capitalista, mas é, antes de mais nada, esse complexo onde as molecularidades ganham velocidade, intensificam-se por força de mil e um encontros. Como a "terceira margem" roseana, o meio do rio não é a relação das duas margens opostos, é o meio intensivo no qual o ente se diz como componente de um todo que é também ele mesmo; o filho e o pai.

Daí a conclusão de que o método dialético, ao incluir a negativa na operação de pensar o Ser reitera, em sua perspectiva, o equívoco, pois o Ser unívoco é todo afirmação. Então, podemos ir a Guimarães Rosa para reconhecer na sua obra a mesma dimensão afirmativa do Ser, na qual Deus e o Diabo ou as margens múltiplas do rio, participam do mesmo elemento sem que haja necessidade de oposição ou exterioridade. Nesse viés, podemos afirmar a categoria do terceiro estado, re-apresentando-o como a solução antidialética de Guimarães Rosa na sua dicção literária do Ser. Há um momento em que é possivel dizer os opostos de modo a revelar a sua unicidade, como o homem que permanece nos meios do rio e assim, traz para si a possibilidade de realizar a existência na sua integralidade afirmativa. O rio como meio corrediço, não mediador.

\section{Entre margens - uma leitura para o conto \\ "A terceira margem do rio", de João Guimarães Rosa}

Silvana Oliveira

Resumo: Este artigo apresenta uma abordagem para o conto "A terceira margem do rio", de João Guimarães Rosa, por 
meio de anotações teóricas que relacionam a noção tradicional de discurso fantástico a conceitos da produção dos filósofos Gilles Deleuze e Felix Guattari. O exercício das anotações teóricas resulta na proposição de uma categoria analitica chamada aqui de terceiro estado; tal categoria é operacionalizada na leitura do conto com vistas a demonstrar os pontos de contato entre o pensamento dos filósofos e o processo criativo, incluída aí a dicção do ser, na obra de João Guimarães Rosa.

Palavras-chave: Guimarães Rosa; teoria literária; filosofia; Gilles Deleuze.

Abstract: This article approaches the short story "The third margin of the river" by João Guimarães Rosa, through theoretical notes which relate the traditional notion of fantastic speech tho concepts of Gilles Deleuze and Felix Guattari's philosophical works. The exercise of theoretical notes results in the proposition of an analytical category called the third state; such category is made instrumental by reading the short story in order to demonstrate the contact points between the phiplosophers' ideas and the creative process, including the diction of being, in the work of João Guimarães Rosa.

Keywords: Guimarães Rosa; literary theory; philosophy; Gilles Deleuze.

Artigo recebido parapublicação em 11/11/2009

Artigo recebido para publicação em 10/12/2009 